\title{
Atmospheric Air Pollution with Tropospheric Ozone on the Example of Selected Rural Villages of the Lubelskie Region
}

\author{
Zbigniew Zuśka ${ }^{1}$, Alicja Baranowska² ${ }^{2}$, Barbara Skowera' \\ 1 Department of Ecology, Climatology and Air Protection, Hugo Kołłątaj University of Agriculture in Krakow, ul. \\ Al. Mickiewicza 24/28, 30-059 Krakow, Poland \\ 2 Department of Agriculture, Pope John Paul II State School of Higher Education, ul. Sidorska 95/98, 21-500 \\ Biała Podlaska, Poland \\ * Corresponding author's e-mail: alabar@tlen.pl
}

\begin{abstract}
In excessive concentrations, the tropospheric ozone (the so-called trioxygen $\mathrm{O}_{3}$ ) constitutes a serious threat to the ecosystems of our planet. It is a threat to the health and life of people. In plants, it contributes to disruption of the most important biochemical processes. The purpose of this study was to assess atmospheric air pollution with tropospheric ozone in selected rural villages of the Lubelskie region in the years 2015-2017. Assessment of air quality in the Lubelskie region in terms of the content of tropospheric ozone, which is significant for the protection of plants and human health, was carried out in accordance with the Regulation of the Minister of Environment of 24 August 2012 on the levels of certain substances in the air, as well as more restrictive guidelines of the World Health Organization. The research used the hourly values of automatic measurements of the tropospheric ozone immission in the years 2015-2017. The data originated from three measurement stations, which function as part of the Air Quality Monitoring System, in three rural communes located in the north-western, central and southern part of the Lubelskie region. As a result of implemented research, no tropospheric ozone concentrations exceeding the threshold values, at which the public should be informed about the risk of exceeding the alarm level, were noted. The highest mean tropospheric ozone immission was recorded during the calendar summer and calendar spring, while the lowest was recorded during the calendar winter and autumn. In terms of human health protection, the largest exceedances of the maximum mean 8-hour value of tropospheric ozone were recorded during the calendar summer at Florianka station, which was located at the highest position ( $270 \mathrm{~m}$ above sea level) in relation to other measurement stations covered by this study. In terms of plant protection, the mean tropospheric ozone concentration, expressed with the use of AOT40, did not exceed the applicable target level $\left(18000 \mu \mathrm{g} \cdot \mathrm{m}^{-3} \cdot \mathrm{h}\right)$ at any of the measurement stations. The highest mean value of AOT40 was recorded at the Florianka meteorological station (14 653.9 $\left.\mu \mathrm{g} \cdot \mathrm{m}^{-3} \cdot \mathrm{h}\right)$, while the lowest was recorded at the Jarczew station $\left(7486.2 \mu \mathrm{g} \cdot \mathrm{m}^{-3} \cdot \mathrm{h}\right)$.
\end{abstract}

Keywords: tropospheric ozone; air pollution; acceptable levels

\section{INTRODUCTION}

Atmospheric air pollution is a global problem and constitutes a serious threat to our planet's ecosystems and biodiversity [Juda-Rezler, 2000; Calvete-Sogo et al., 2016; Ghorani-Azam et al., 2016; Malec and Borowski, 2016].

According to the report of the European Environment Agency, the most dangerous air pollutants include: particulate matter (PM), nitrogen dioxide $\left(\mathrm{NO}_{2}\right)$ and near-surface ozone $\left(\mathrm{O}_{3}\right)$. Ozone is a natural component of the atmosphere - it plays a very important role in the stratosphere (in the so-called ozone layer, ozonosphere), because it protects our planet from UVB radiation, which is extremely harmful to living organisms [Dziewulska-Łosiowa and Hryniewicz, 1993; Harmens and Mills, 2012]. On the other hand, the tropospheric ozone - occurring in excessive amounts in the near-earth troposphere layer 
(exceeding the permissible standards, which are determined by provisions of the law) is a harmful secondary pollutant. It is created as a result of complex photochemical reactions in the presence of nitrogen oxides, hydrocarbons and carbon oxides, which constitute the so-called primary pollutants, and they mainly originate from road transport. High temperature and high intensity of solar radiation are conducive to these reactions [Juda-Rezler, 2000; Nali et al., 2001; Naser et al., 2008; Air quality in Europe, 2018].

Tropospheric ozone is characterised by a negative impact on human and animal health, as well as ecosystem and climate [Directive 2008/50/ EC, 2008; Mauzerall and Wang, 2001; Shindell et al., 2012; Mills et al., 2013; Alonso et al., 2014]. Increased ozone concentrations constitute a significant health problem, causing a series of negative effects, which are expressed in the increase in mortality due to cardiovascular and respiratory diseases [Skotak, 2010; Krzyżanowski, 2016; Wojdat et al., 2016). According to data of the European Environment Agency, high concentrations of tropospheric ozone caused premature death of approx. 18000 people in 41 European countries [European Environment Agency, 2018].

The ozone concentration level at which the public is informed about the risk of alarm level amounts to $180 \mu \mathrm{g} \cdot \mathrm{m}^{-3}$ (1-hour mean), while the alarm level amounts to $240 \mu \mathrm{g} \cdot \mathrm{m}^{-3}$ (1-hour mean) [Regulation of the Minister of the Environment, 2012].

Moreover, the tropospheric ozone is one of the most important air pollutants causing damage to cultivated plants and constitutes a serious threat to the production of plant biomass [Saitanis et al., 2001; Borowiak et al., 2008; Zapletal et al., 2011; Mills et al., 2013]. Braun et al. (2014) also observed a negative impact of the ozone on forest ecosystems. According to Alonso et al. [2014], the tropospheric ozone constitutes an additional stress factor, which hinders adaptation of the plants to the climate change.

Ozone concentration in the near-earth atmosphere layer is characterised by high spatial and temporal variability [Klingberg et al., 2012; Vingarzan, 2004]. The level of this gas's concentration changes throughout the day and in the annual scale. The daily maximum is observed in the afternoon hours, while in the annual cycle, it is observed in the spring and summer months. The size of immission depends on chemical composition of the air, atmospheric conditions and local topography
[Dziewulska-Łosiowa and Hryniewicz, 1993; Castell et al., 2008; Khoder, 2009; Statistical Yearbook for Environment Protection, 2018].

In contrast to other air pollutants, whose highest concentrations occur in large cities, the highest concentrations of tropospheric ozone are usually recorded outside the agglomerations, on their leeward side [Juda-Rezler, 2000].

Lublin Voivodeship, which in this study is referred to as the Lubelskie region, is located in south-eastern Poland, between the Vistula river and the Bug river. According to the Kondracki classification [2002], this area is located in the province of Lublin-Lviv Upland. The north-eastern part is Polesie, while the north-western part belongs to the Central Poland Lowlands. The eastern border of this voivodeship is the state border of Poland with Belarus and Ukraine, as well as the border of the European Union (EU). The Lubelskie region is a typical agricultural region with the highest share of cultivated land in Poland - cultivated land constitutes $70.0 \%$ of the total area of this voivodeship. The potential of nature in this region is more favourable compared to the mean values in Poland. Therefore, the purpose of this study was to assess atmospheric air pollution with tropospheric ozone in selected measurement stations, located in rural communes within the Lubelskie region.

\section{MATERIAL AND METHODS}

The research used hourly (according to Central European Time CET) values of automatic measurements of tropospheric ozone immission in the years 2015-2017. The data originated from the following measurement stations: Wilczopole, Jarczew and Florianka, functioning within the framework of the Air Quality Monitoring System, located in the rural communes of the Lublin Voivodeship (Lubelskie region). Characteristics of these stations are presented in Table 1.

Assessment of air quality in the Lubelskie region in terms of the content of tropospheric ozone, which is significant for the protection of plants and human health, was carried out in accordance with the Regulation of the Minister of Environment of 24 August 2012 on the levels of certain substances in the air [Regulation..., 2012]. Within this document, the target level and the level of long-term tropospheric ozone goal in the context of human health protection is defined as 
Table 1. Geographical location of meteorological stations covered by this study

\begin{tabular}{|l|c|c|c|c|c|}
\hline $\begin{array}{c}\text { Name of the meteorological } \\
\text { station / national code / } \\
\text { international code }\end{array}$ & $\begin{array}{c}\text { Latitude } \\
(\varphi) \mathrm{N}\end{array}$ & $\begin{array}{c}\text { Longitude } \\
(\lambda) \mathrm{E}\end{array}$ & $\begin{array}{c}\text { Height } \\
\text { above sea } \\
\text { level }\end{array}$ & $\begin{array}{c}\text { Mesoregion according } \\
\text { to Kondracki }(2002)\end{array}$ & $\begin{array}{c}\text { Type of station / } \\
\text { owner }\end{array}$ \\
\hline $\begin{array}{l}\text { Wilczopole/ } \\
\text { LbWilczopole/ } \\
\text { PL0488A }\end{array}$ & $51^{\circ} 09^{\prime} 49^{\prime \prime}$ & $22^{\circ} 35^{\prime} 55^{\prime \prime}$ & 202 & $\begin{array}{c}\text { Płaskowyż Świdnicki } \\
(343.16)\end{array}$ & $\begin{array}{l}\text { Non-urban background / } \\
\text { Voivodeship Inspectorate of } \\
\text { Environmental Protection in } \\
\text { Lublin }\end{array}$ \\
\hline $\begin{array}{l}\text { IMGW-Jarczew/ } \\
\text { LbJarczWolaM } \\
\text { / PL0002R }\end{array}$ & $51^{\circ} 48^{\prime} 52^{\prime \prime}$ & $21^{\circ} 58^{\prime} 21^{\prime \prime}$ & 177 & $\begin{array}{l}\text { Won-urban background / } \\
\text { Zysoczyzna } \\
\text { Institute of Meteorology and } \\
\text { Water Management - National } \\
\text { Research Institute }\end{array}$ \\
\hline $\begin{array}{l}\text { Florianka RPN/ } \\
\text { LbFlorianRPN/ PL0691A }\end{array}$ & $50^{\circ} 33^{\prime} 07^{\prime \prime}$ & $22^{\circ} 58^{\prime} 58^{\prime \prime}$ & 270 & $\begin{array}{c}\text { Roztocze Środkowe } \\
(343.22)\end{array}$ & $\begin{array}{l}\text { Non-urban background / } \\
\text { Roztocze National Park }\end{array}$ \\
\hline
\end{tabular}

Source: Own elaboration based on: Kondracki [2002]; Bank of measurement data of the Inspectorate of Environmental Protection [2019].

the maximum 8-hour mean among moving means calculated from 1-hour concentrations within a day. The target level is met, if the number of days exceeding the value of $120 \mu \mathrm{g} \cdot \mathrm{m}^{-3}$, averaged over three years, amounts to no more than 25 . The condition for compliance with the long-term goal is the absence of exceedances of the value 120 $\mu \mathrm{g} \cdot \mathrm{m}^{-3}$. The WHO guidelines are more restrictive and they assume $100 \mu \mathrm{g} \cdot \mathrm{m}^{-3}$ as the maximum concentration for the moving mean. Also, the exceedances of this mean are not allowed [World Health Organization (WHO), 2006].

The AOT40 parameter (Accumulated Ozone exposure over a Threshold of $40 \mathrm{ppb}\left(=80 \mu \mathrm{g} / \mathrm{m}^{3}\right)$ is an indicator of air quality assessment for tropospheric ozone in the context of plant protection. It determines the cumulative dose of ozone above the threshold concentration of $40 \mathrm{ppb}\left(80 \mu \mathrm{g} \cdot \mathrm{m}^{-3}\right)$ Higher doses of $\mathrm{O}_{3}$ above this level are toxic to plants and its harmfulness increases proportionally to the time of exposure. This applies to the daytime, when the most intensive gas exchange takes place through the plant stomata. In order to calculate AOT40, it is necessary to add the differences between the measured ozone concentration (1-hour mean) and the threshold value. Calculations are carried out for the period of the most intensive plant vegetation, taking into account daily hours (between $8^{00}$ and $20^{00} \mathrm{CET}$ ) and only the concentrations above $40 \mathrm{ppb}$ [Borowiak et al., 2008]. Due to the protection of plants during the vegetation period (1V-31VII), the permissible level of tropospheric ozone, calculated in this manner, cannot exceed $18000 \mu \mathrm{g} \cdot \mathrm{m}^{-3} \cdot \mathrm{h}$ (mean value). On the other hand, the level of the longterm goal should amount to $6000 \mu \mathrm{g} \cdot \mathrm{m}^{-3} \cdot \mathrm{h}$.

As the background of these indicators, the basic statistical characteristics of the tropospheric ozone concentration were calculated. These values included: mean, the highest value, the lowest value and standard deviation. These characteristics were calculated for months, seasons and years.

\section{RESULTS AND DISCUSSION}

In terms of human health protection, the biggest number of days, in which occurred exceedances of the maximum mean 8-hour value of tropospheric ozone, was recorded at Florianka meteorological station, which is located the highest above sea level compared to other analysed stations ( $270 \mathrm{~m}$ above sea level) (Table 1 and Table 4). These results are confirmed by the research of Wróblewski [2006], who stated that the value of ozone concentration is strictly associated with geographical location of the measurement point, and for every $100 \mathrm{~m}$ of height increase, the ozone concentration increases by $1.58 \mu \mathrm{g} \cdot \mathrm{m}^{-3}$.

The largest exceedances of the maximum 8-hour mean $\mathrm{O}_{3}$ value at each monitoring station covered by this study were recorded during the calendar summer, while the largest exceedances occurred in the warmest season of 2015 , compared to the other years of research, in which the mean annual area air temperature in the Lublin Voivodeship amounted to $9.5^{\circ} \mathrm{C}$. The warmest month was August, with the maximum daily air temperature amounting to $35.4^{\circ} \mathrm{C}$ [Voivodeship Inspectorate...2016].

During the summer of 2015, also at the Florianka station, 26 days were recorded with exceedances of the maximum mean 8-hour ozone value $>120 \mu \mathrm{g} \cdot \mathrm{m}^{-3}$ (the Polish law allows 25 days a year) and 46 days with exceedances of the value $>100 \mu \mathrm{g} \cdot \mathrm{m}^{-3}$ [World Health Organization (WHO), 
2013]. On the other hand, during the calendar winter, no exceedances of the maximum mean 8-hour value $>120 \mu \mathrm{g} \cdot \mathrm{m}^{-3}$ occurred in the individual years in any of the analysed stations, however these exceedances were recorded in the case of the value $>100 \mu \mathrm{g} \cdot \mathrm{m}^{-3}$, also at the Florianka monitoring station, and they amounted to (respectively): 2014/2015 - 1 day and 2016/2017 - 3 days (Table 4). Moreover, according to Kalbarczyk et al. [2015], the level of tropospheric ozone concentration is characterised by high annual and seasonal variability, which is significantly affected by meteorological conditions and NOx level (one of the ozone precursors), than on the average the intensity of solar radiation and atmospheric air temperature, as well as air humidity below average.

The impact of meteorological conditions (particularly thermal conditions) on the value of tropospheric ozone concentration is known and documented in the Polish scientific literature, as well as the foreign scientific literature [Tirabassi et al., 2005; Nidzgorska-Lencewicz, 2008; Ooka et al., 2011; Rozbicka and Michalak, 2015; Oyola et al., 2018]. Beck et al. [1998] stated that the cases of occurrence of high ozone concentrations may also depend on the direction and speed of wind (transport of ozone and its precursors, as well as mixing intensity), therefore they may be of transboundary nature and they may be the result of the inflow of polluted air masses from other areas.

While analysing the concentration of tropospheric ozone in the context of plant protection, expressed with the use of AOT40, it was found that the mean value of this parameter in the years of research (2015-2017) did not exceed the applicable target level $\left(18000 \mu \mathrm{g} \cdot \mathrm{m}^{-3} \cdot \mathrm{h}\right)$ in any of the measurement

Table 2. The number of days, in which occurred the exceedances of maximum mean 8-hour value of tropospheric ozone in the selected monitoring stations of the Lubelskie region (2015-2017)

\begin{tabular}{|c|c|c|c|c|c|c|}
\hline \multicolumn{4}{|c|}{$\begin{array}{l}\text { The number of days, in which occurred the exceedances of maximum } \\
\text { mean 8-hour value of tropospheric ozone }\left(\mathrm{O}_{3}\right)>120 \mathrm{\mu g} \cdot \mathrm{m}^{-3^{*}}\end{array}$} & \multicolumn{3}{|c|}{$\begin{array}{l}\text { The number of days, in which occurred the } \\
\text { exceedances of maximum mean } 8 \text {-hour value } \\
\text { of tropospheric ozone }\left(\mathrm{O}_{3}\right)>100 \mu \mathrm{g} \cdot \mathrm{m}^{-3^{* *}}\end{array}$} \\
\hline Meteorological station & Florianka & Jarczew & Wilczopole & Florianka & Jarczew & Wilczopole \\
\hline Year / Season & \multicolumn{6}{|c|}{ Spring } \\
\hline 2015 & 4 & 1 & 0 & 23 & 15 & 10 \\
\hline 2016 & 1 & 0 & 0 & 20 & 19 & 1 \\
\hline 2017 & 1 & 0 & 0 & 21 & 4 & 9 \\
\hline \multicolumn{7}{|c|}{ Summer } \\
\hline 2015 & 26 & 13 & 15 & 46 & 35 & 34 \\
\hline 2016 & 1 & 1 & 2 & 28 & 12 & 11 \\
\hline 2017 & 10 & 0 & 4 & 41 & 12 & 24 \\
\hline \multicolumn{7}{|c|}{ Autumn } \\
\hline 2015 & 1 & 1 & 1 & 5 & 2 & 2 \\
\hline 2016 & 2 & 2 & 0 & 11 & 6 & 5 \\
\hline 2017 & 1 & 0 & 1 & 1 & 0 & 1 \\
\hline \multicolumn{7}{|c|}{ Winter } \\
\hline $2014 / 2015$ & 0 & 0 & 0 & 1 & 0 & 0 \\
\hline $2015 / 2016$ & 0 & 0 & 0 & 0 & 0 & 0 \\
\hline $2016 / 2017$ & 0 & 0 & 0 & 3 & 0 & 0 \\
\hline \multicolumn{7}{|c|}{ In total for the years: } \\
\hline 2015 & 31 & 15 & 16 & 75 & 52 & 46 \\
\hline 2016 & 4 & 3 & 2 & 59 & 37 & 17 \\
\hline 2017 & 12 & 0 & 5 & 66 & 16 & 34 \\
\hline
\end{tabular}

Source: Own elaboration based on the Bank of measurement data of the Inspectorate of Environmental Protection, powietrze.gios.gov.pl [access on 12.07.2019].

*According to the Regulation of the Minister of Environment, Journal of Laws 2012, item 1031, due to the protection of human health, the target level $0_{3}$, which is calculated as the moving mean for eight hours in a given day - should not exceed $120 \mu \mathrm{g} \cdot \mathrm{m}^{3}$. The law allows 25 days in the calendar year, when moving means may exceed this value (calculated as a mean for three years).

** WHO (World Health Organization) guidelines are more restrictive and they assume $100 \mu \mathrm{g} \cdot \mathrm{m}^{3}$ as the maximum concentration for the moving mean. Also, the exceedances of this mean are not allowed [WHO, 2006]. 
stations. The highest mean value of AOT40 was recorded at the Florianka meteorological station (14 $653.9 \mu \mathrm{g} \cdot \mathrm{m}^{-3} \cdot \mathrm{h}$ ), while the smallest at the Jarczew station (7 $\left.486.2 \mu \mathrm{g} \cdot \mathrm{m}^{-3} \cdot \mathrm{h}\right)$. The Regulation of the Minister of Environment of 2012 also determines the level of long-term goal for tropospheric ozone, which should be reached in 2020 and it amounts to $6000 \mu \mathrm{g} \cdot \mathrm{m}^{-3} \cdot \mathrm{h}$. In the analysed period, no such value was recorded in any of the stations, however the annual decrease in AOT40 value was observed in the years of research and if this trend will maintain in the future, then Jarczew and Wilczopole stations have greater chances of reaching the long-term target level $\left(6000 \mu \mathrm{g} \cdot \mathrm{m}^{-}\right.$ $\left.{ }^{3} \cdot h\right)$. In the analysed period, the lowest AOT40 value was recorded in 2017 at the Jarczew station and it amounted to $4067.8 \mu \mathrm{g} \cdot \mathrm{m}^{-3} \cdot \mathrm{h}$ (Table 3).

The data presented in Table 2 indicate that in the years of research (2015-2017), no tropospheric ozone concentrations were recorded in any of the measurement stations, at which the public should be informed about the risk of alarm level (180 $\mu \mathrm{g} \cdot \mathrm{m}^{-3}, 1$-hour mean) and about the risk of exceeding the alarm level $\left(240 \mu \mathrm{g} \cdot \mathrm{m}^{-3}\right.$, 1-hour mean) (Regulation ..., 2012). In the analysed period, the highest ozone concentration was recorded in August (during high air temperatures) at the Wilczopole measurement station $\left(178 \mu \mathrm{g} \cdot \mathrm{m}^{-3}\right)$, followed by Jarczew $\left(160.9 \mu \mathrm{g} \cdot \mathrm{m}^{-3}\right)$ and Florianka $\left(158.2 \mu \mathrm{g} \cdot \mathrm{m}^{-3}\right)$ (Table 4). Whereas in September, the highest ozone concentrations were recorded at the Jarczew station $\left(162.8 \mu \mathrm{g} \cdot \mathrm{m}^{-3}\right)$, Florianka $\left(152.6 \mu \mathrm{g} \cdot \mathrm{m}^{-3}\right)$ and Wilczopole $(146.6$ $\left.\mu \mathrm{g} \cdot \mathrm{m}^{-3}\right)$. It was concluded that the calendar summer (months VI-VIII) was characterised by the highest mean immission of tropospheric ozone: Florianka $68 \mu \mathrm{g} \cdot \mathrm{m}^{-3}$, Wilczopole $63 \mu \mathrm{g} \cdot \mathrm{m}^{-3}$, Jarczew $58 \mu \mathrm{g} \cdot \mathrm{m}^{-3}$, followed by the calendar spring (months III-V): Florianka $64 \mu \mathrm{g} \cdot \mathrm{m}^{-3}$ (the highest in April), Jarczew $58 \mu \mathrm{g} \cdot \mathrm{m}^{-3}$ (the highest in
April) and Wilczopole $57 \mu \mathrm{g} \cdot \mathrm{m}^{-3}$ (the highest in May). Lower ozone concentrations were recorded during the calendar autumn (months IX-XI) and winter (months XII-II). In the case of calendar autumn and winter, on average it amounted to: at the Florianka station 42 and $45 \mu \mathrm{g} \cdot \mathrm{m}^{-3}$, Jarczew 36 and $38 \mu \mathrm{g} \cdot \mathrm{m}^{-3}$, Wilczopole $36 \mu \mathrm{g} \cdot \mathrm{m}^{-3}$. While analysing the values of standard deviation, it was concluded that the calendar winter was characterised by the smallest dispersion of ozone concentration, while the greatest dispersion occurred during the months of calendar summer, spring and partially the calendar autumn (Table 4).

While analysing the results of own research in the context of entire country, it must be concluded that in the years 2015-2017 in the area of Poland, 2015 was characterised by the greatest number of cases with tropospheric ozone concentrations exceeding the threshold values and the need to inform the public about the risk of exceeding the alarm level, and consequently the risk to human health, when 12 measurement stations in 10 Polish cities exceeded the level of informing the public $\left(180 \mu \mathrm{g} \cdot \mathrm{m}^{-3}\right.$, for 1-hour concentrations) (State Environmental Monitoring, 2016). The highest 1-hour ozone concentrations were recorded in southern and south-western Poland: in Legnica $\left(201 \mu \mathrm{g} \cdot \mathrm{m}^{-3}\right)$, in the following agglomerations: Rybnicko-Jastrzębska, Górnośląska, Krakowska, Poznańska, Łódzka and in the following cities: Częstochowa, Tarnów, Rzeszów, Bielsko Biała. In 2016, the level of informing the public was exceeded only in Rybnik $\left(189 \mu \mathrm{g} \cdot \mathrm{m}^{-3}\right)$ [State Environmental Monitoring, 2017]. In 2017, the level of informing the public was exceeded in Katowice $\left(184 \mu \mathrm{g} \cdot \mathrm{m}^{-3}\right)$ and in Zabrze [State Environmental Monitoring, 2018]. In the years 20152017, no measurement station in Poland recorded the exceeding of ozone alarm level $\left(240 \mu \mathrm{g} \cdot \mathrm{m}^{-3}\right.$, for 1-hour concentrations).

Table 3. Tropospheric ozone concentration in the context of plant protection, expressed with the use of AOT40* in selected meteorological stations of the Lubelskie region (2015-2017)

\begin{tabular}{|c|c|c|c|}
\hline \multirow{2}{*}{ Name of the meteorological station / Year } & \multicolumn{3}{c|}{ Jarczew } \\
\cline { 2 - 4 } & \multicolumn{3}{c|}{$\mu \mathrm{g} \cdot \mathrm{m}^{-3} \cdot \mathrm{h}$} \\
\hline 2015 & 18059.3 & 9256.2 & 10409.6 \\
\hline 2016 & 12586.9 & 9134.7 & 8123.1 \\
\hline 2017 & 13315.4 & 4067.8 & 7675.6 \\
\hline Mean & 14653.9 & 7486.2 & 8736.1 \\
\hline
\end{tabular}

*AOT40 (Accumulated Ozone exposure over a Threshold of $40 \mathrm{ppb}\left(=80 \mu \mathrm{g} \cdot \mathrm{m}^{-3}\right)$.

Source: Own elaboration based on the Bank of measurement data of the Inspectorate of Environmental Protection, powietrze.gios.gov.pl [access 12.07.2019]. 
Table 4. Average, the highest, the lowest value and standard deviation of tropospheric ozone concentration in selected stations in the Lubelskie region (2015-2017) for 1-hour values

\begin{tabular}{|c|c|c|c|c|c|c|c|c|c|c|c|c|c|c|}
\hline \multirow{2}{*}{ Station } & \multicolumn{14}{|c|}{ Value of tropospheric ozone concentration $\mathrm{O}_{3}\left(\mu \mathrm{g} \cdot \mathrm{m}^{-3}\right)$} \\
\hline & Months & I & II & III & IV & $\mathrm{V}$ & VI & VII & VIII & IX & $\mathrm{X}$ & $\mathrm{XI}$ & XII & I-XII \\
\hline \multirow{4}{*}{ Florianka } & Mean & 45.2 & 54.5 & 58.5 & 68.5 & 65.2 & 71.6 & 64.3 & 66.5 & 51.2 & 38.8 & 34.5 & 35.5 & 54.4 \\
\hline & The Highest & 94.4 & 127.2 & 122.5 & 137.4 & 125.4 & 145.8 & 152.8 & 158.2 & 152.6 & 97.2 & 80.5 & 71.6 & 158.2 \\
\hline & The Lowest & 2.9 & 2.1 & 2.5 & 1.5 & 1.8 & 1.7 & 1.4 & 0.9 & 0.6 & 0.4 & 1.5 & 2.3 & 0.4 \\
\hline & \begin{tabular}{|l|} 
Standard \\
deviation
\end{tabular} & 17.7 & 22.1 & 23.2 & 26.0 & 30.9 & 29.5 & 32.0 & 36.0 & 29.9 & 20.5 & 15.2 & 15.0 & 28.9 \\
\hline \multirow{4}{*}{ Jarczew } & Mean & 36.7 & 46.0 & 49.1 & 61.2 & 62.8 & 61.9 & 54.7 & 58.2 & 44.3 & 34.6 & 29.0 & 30.1 & 47.4 \\
\hline & The Highest & 97.3 & 103.7 & 115.6 & 126.0 & 124.0 & 139.5 & 147.0 & 160.9 & 162.8 & 93.6 & 68.2 & 66.7 & 162.8 \\
\hline & The Lowest & 0.0 & 1.0 & 2.6 & 8.0 & 0.0 & 2.0 & 0.7 & 1.2 & 0.0 & 0.0 & 0.2 & 0.2 & 0.0 \\
\hline & \begin{tabular}{|l|} 
Standard \\
deviation
\end{tabular} & 15.5 & 18.0 & 19.2 & 20.3 & 25.3 & 24.8 & 26.1 & 32.0 & 25.1 & 17.2 & 13.7 & 14.5 & 24.8 \\
\hline \multirow{4}{*}{ Wilczopole } & Mean & 35.6 & 44.4 & 49.3 & 61.1 & 61.9 & 65.9 & 59.8 & 62.3 & 45.0 & 34.0 & 30.0 & 29.1 & 48.1 \\
\hline & The Highest & 77.4 & 96.0 & 115.5 & 124.0 & 125.6 & 143.7 & 148.1 & 178.4 & 146.6 & 84.9 & 70.0 & 63.0 & 178.4 \\
\hline & The Lowest & 1.4 & 2.3 & 2.7 & 3.3 & 4.5 & 4.6 & 3.0 & 1.7 & 1.5 & 1.9 & 1.8 & 1.8 & 1.4 \\
\hline & $\begin{array}{l}\text { Standard } \\
\text { deviation }\end{array}$ & 14.9 & 17.0 & 18.8 & 19.7 & 23.5 & 26.8 & 27.7 & 31.4 & 23.9 & 16.5 & 13.8 & 13.7 & 25.1 \\
\hline
\end{tabular}

Source: Own elaboration based on the Bank of measurement data of the Inspectorate of Environmental Protection, www.powietrze.gios.gov.pl [access 12.07.2019].

\section{CONCLUSIONS}

1. As a result of implemented research, no tropospheric ozone concentrations exceeding the threshold values, at which the public should be informed about the risk of exceeding the alarm level, were recorded.

2. In terms of human health protection, the largest exceedances of the maximum mean 8-hour value of tropospheric ozone were recorded during the calendar summer at Florianka station, which was located at the highest position (270 $\mathrm{m}$ above sea level) in relation to other measurement stations covered by this study.

3. In terms of plant protection, the mean tropospheric ozone concentration, expressed with the use of AOT40, did not exceed the applicable target level $\left(18000 \mu \mathrm{g} \cdot \mathrm{m}^{-3} \cdot \mathrm{h}\right)$ at any of the measurement stations. The highest mean value of AOT40 was recorded at the Florianka meteorological station $\left(14653.9 \mu \mathrm{g} \cdot \mathrm{m}^{-3} \cdot \mathrm{h}\right)$, while the lowest was recorded at the Jarczew station (7 $\left.486.2 \mu \mathrm{g} \cdot \mathrm{m}^{-3} \cdot \mathrm{h}\right)$.

4. The highest mean tropospheric ozone immission was recorded during the calendar summer and calendar spring, while the lowest was recorded during the calendar winter and autumn.

\section{Acknowledgements}

This research was financed by the Ministry of Science and Higher Education of the Republic of Poland.

\section{REFERENCES}

1. Air quality in Europe - 2018 report. European Environment Agency (EEA) Report No 12/2018. Luxemburg. Publications Office of the European Union.

2. Alonso, R., Elvira, S., González-Fernández, I., Calvete, H., García-Gómez, H., Bermejo, V. 2014. Drought stress does not protect Quercus ilex L. from ozone effects: results from a comparative study of two subspecies differing in ozone sensitivity. Plant Biology, 16, 375-384.

3. Bank of measurement data of the Inspectorate of Environmental Protection. 2019. www.powietrze. gios.gov.pl [access 12.07.2019].

4. Beck J.P., Krzyzanowski M., Koffi B., Hjellbrekke A.-G., Hootsen H., Millán M., Tombrou M., Simpson D. 1998. Tropospheric Ozone in the European Union. The Consolidated Report. Topic report, 8.

5. Borowiak K., Zbierska J., Ławniczak A.E., Tomaszewska M. 2008. Characteristics of reactions of Nicotiana tabacum to Troposphere ozone in the territory of the city of Poznań and its vicinity. Problemy Ekologii Krajobrazu, XXII, 115-126. [in Polish].

6. Braun S., Schindler C., Rihm B. 2014. Growth losses in Swiss forests caused by ozone: Epidemiological 
data analysis of stem increment of Fagus sylvatica L. and Picea abies Karst. Environmental Pollution, 192, 129-138.

7. Calvete-Sogo H., González-Fernández I., Sanz, J., Elvira S., Alonso R., García-Gómez H., Ibáñez-Ruiz M.A., Bermejo-Bermejo V. 2016. Heterogeneous responses to ozone and nitrogen alter the species composition of Mediterranean annual pastures. Oecologia, 181, 1055-1067.

8. Castell N., Mantilla E., Millan M.M., 2008. Analysis of tropospheric ozone concentration on a Western Mediterranean site: Castellon (Spain). Environ. Monit. Assessm., 136, 3-11.

9. Directive 2008/50/EC of the European Parliament and of the Council of 21.05.2008 on ambient air quality and cleaner air for Europe (EU Journal of Laws L 152 of 11.06.2008).

10. Dziewulska-Łosiowa A., Hryniewicz R. 1993. Ozone in the stratosphere and troposphere. Kosmos 42, 79-94. [in Polish]

11. European Environment Agency (EEA). 2018. Air quality in Europe - 2018 report. Report No 12/2018. Luxemburg. Publications Office of the European Union.

12. Ghorani-Azam A., Riali-Zanjani B., Balali-Mood M. 2016. Effects of air pollution on human health and practical measures for prevention in Iran. Journal of Research in Medical Science, 21.

13. Harmens H., Mills G. (Eds.) 2012. Ozone pollution: Impacts on carbon sequestration in Europe. ICP Vegetation Programme Coordination Centre, CEH Bangor, UK.

14. Juda-Rezler K. 2000. Impact of air pollutants on the environment. Ofic. Wydaw. Polit. Warsz. Warszawa. [in Polish]

15. Kalbarczyk R., Kalbarczyk E., NiedźwieckaFilipiak I., Serafin L. 2015. Concentration of ozone near earth surface depending on the content of NOx and meteorological conditions. Ecological Chemistry and Engineering, 22 (4), 527-541.

16. Khoder M.I. 2009. Diurnal, seasonal and weekdaysweekends variations of ground level ozone concentrations in an urban area in greater Cairo. Environ. Monit. Assessm., 149, 349-362.

17. Klingberg J., Karlsson P.E., Pihl Karlsson G., Hu Y., Chen D., Pleijel H., 2012. Variation in ozone exposure in the landscape of southern Sweden with consideration of topography and coastal climate. Atmospheric Environment, 47, 252-260

18. Kondracki J. 2002. Regional geography of Poland. PWN, Warszawa. [in Polish]

19. Krzyżanowski M. 2016. Impact of air pollution with dusts on cardiovascular and respiratory systems. Lekarz Wojskowy, 1, 17-22. [in Polish]

20. Malec A., Borowski G. 2016. The hazards of dusting and monitoring of atmospheric air. Ecological Engineering, 50, 161-170.

21. Mauzerall D.L., Wang X. 2001. Protecting agriculture crops from the effects of tropospheric ozone exposures: Reconciling science and standard setting in the limited States, Europe and Asia. Annual Reviews Energy and the Environment. 26, 237-268.

22. Mills G., Wagg S., Harmens H. 2013. Ozone pollution: Impacts on ecosystem services and biodiversity. ICP Vegetation Programme Coordination Centre, Centre for Ecology and Hydrology, Bangor, UK.

23. Nali C., Ferretti M., Pellegrini M., Loreznini G. 2001. Monitoring and biomonitoring of surface ozone in Florence, Italy. Environmental Monitoring and Assessment, 69, 159-174.

24. Naser T. M., Yoshimura Y., Sekiguchi K., Wang Q., Sakamoto K. 2008. Chemical composition of PM ${ }_{2,5}$ and $\mathrm{PM}_{10}$ and associated polyclic aromatic hydrocarbons at a roadside and an urban background area in Saitama. Asian Journal of Atmospheric Environment, 2-2, 90-101.

25. Nidzgorska-Lencewicz J., 2008. Meteorological elements determining the concentration of ozone in Szczecin. 8th Ann. Meet. of the European Meteorological Society - 7th Europ. Conf. on Applied Climatology (ECAC), Amsterdam, 29 IX - 3 X 2008. Abstracts 5.

26. Ookaa R., Khiemb M., Hayamic H., Hiroshi Yoshikado H., Huange H., Kawamotoa Y. 2011. Influence of meteorological conditions on summer ozone levels in the central Kanto area of Japan. Procedia Environmental Sciences, 4, 138-150

27. Oyola M., I., Schneider A., Campbell J., Everette J. 2018. Meteorological Influences on Tropospheric Ozone over Suburban Washington, DC. Aerosol and Air Quality Research, 18, 1168-1182.

28. Regulation of the Minister of Environment of 24 August 2012 on the levels of certain substances in the air. Journal of Laws of 8 September 2012, item 1031. [in Polish]

29. Rozbicka K., Michalak M. 2015. Characteristic of selected air pollutants concentration in Warsaw (Poland). Przegląd Naukowy - Inżynieria i Kształtowanie Środowiska, 68, 193-206. [in Polish]

30. Saitanis C.J., Riga-Karandinos A.N., Karandinos M.G. 2001. Effects of ozone on chlorophyll and quantum yield of tobacco (Nicotiana tabacum L.) varieties. Chemosphere, 42, 945-953.

31. Shindell D., Kuylenstierna J. C. I., Vignati E., van Dingenen R., Amann M., Klimont Z., Anenberg S. C., Muller N., Janssens-Maenhout G., Raes F., Schwarz J., Faluvegi G., Pozwoli L., Kupiainen K., Höglund-Isaksson L., Emmerson L., Streets D., Ramanathan V., Hicks K., Oanh N. T. K., Milly G., 
Williams M., Demkine V., Fowler D. 2012. Simultaneously Mitigating Near-Term Climate Change and Improving Human Health and Food Security. Science, 335, 183-189.

32. Skotak K. 2010. Ozone concentration attributable premature death in Poland. Medycyna Środowiskowa / Environmental Medicine, 13 (1), 30-40.

33. State Environment Monitoring. 2016. Air quality in Poland in 2015 in light of the results of measurements carried out under the State Environment Monitoring. Warszawa. [in Polish]

34. State Environment Monitoring. 2017. Air quality in Poland in 2016 in light of the results of measurements carried out under the State Environment Monitoring. Warszawa. [in Polish]

35. State Environment Monitoring. 2018. Air quality in Poland in 2017 in light of the results of measurements carried out under the State Environment Monitoring. Warszawa. [in Polish]

36. Statistical Yearbook for Environment Protection. 2018. Central Statistical Office, Department of Spatial and Environmental Research. Warszawa. [in Polish]

37. Tirabassi T., Cocci Grifoni R., Passerini G. 2005. The representative day technique in the study of photochemical smog pollution in falconara industrial area. Water, Air, and Soil Pollution, 166, $65-81$
38. Vingarzan R. 2004. A review of surface ozone background levels and trends. Atmospheric Environment, 38, 3431-3442.

39. Voivodeship Inspectorate for Environmental Protection. 2016. Air quality assessment in the Lublin Voivodeship for 2015. Lublin. [in Polish]

40. Wojdat M., Stańczyk A., Gielerak G. 2016. Air pollution versus diseases of cardiovascular system - underestimated problem. Lekarz Wojskowy, 1, 10-16. [in Polish]

41. World Health Organization (WHO). 2006. Air quality guidelines for particulate matter, ozone, nitrogen dioxide and sulfur dioxide. Global update 2005. Summary of risk assessment.

42. World Health Organization (WHO). 2013. Review of evidence on health aspects of air pollution. REVIHAAP Project.

43. Wróblewski H. 2006. The comparison of measurements near-surface ozone concentration on chosen European stations. Kieleckie Towarzystwo Naukowe. Monitoring Środowiska Przyrodniczego, 7 , 33-37. [in Polish]

44. Zapletal M., Cudlín P., Chroust P., Urban O., Pokorný R., Edwards-Jonášová M., Czerný R., Janouš D., Taufarová K., Večeŕa Z., Mikuška P., Paoletti E. 2011. Ozone flux over a Norway spruce forest and correlation with net ecosystem production. Environmental Pollution, 159, 1024-1034. 